\title{
The Relationship Between Generalized Joint Hypermobility and Cervical Disc Degeneration, Neck Pain: A Multidisciplinary Clinical Study
}

\author{
Neşe Keser, ${ }^{1}$ (1) Esin Derin Çiçek, ${ }^{2}$ (1) Arzu Atıcı, ${ }^{3}$ (1) Pınar Akpınar, ${ }^{3}$ \\ (1) Özge Gülsüm IIlleez, ${ }^{3}$ (1) Ahmet Eren Seçen ${ }^{1}$
}

'Department of Neurosurgery, İstanbul Fatih Sultan Mehme Training and Research Hospital, Istanbul, Turkey

${ }^{2}$ Department of Radiology, İstanbu Fatih Sultan Mehmet Training and Research Hospital, İstanbul, Turkey

${ }^{3}$ Department of Physical Therapy and Rehabilitation, İstanbul Fatih Sultan Mehmet Training and Research Hospital, İstanbul, Turkey

Submitted: 11.10 .2018 Accepted: 03.01.2019

Correspondence: Neșe Keser, Istanbul Fatih Sultan Mehmet Eğitim ve Araştırma Hastanesi, Beyin Cerrahisi Kliniği, İstanbul, Turkey E-mail:nskeser@gmail.com

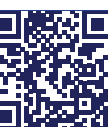

Keywords: Cervical spine; disc degeneration; generalized joint hypermobility; Neck

Disability Index; neck pain; Visual Analog Scale.

\section{(c) (1) \$)}

This work is licensed under a Cretive Conmons This work is ticensed 14 I

\begin{abstract}
Objective: Generalized joint hypermobility $(\mathrm{GJH})$ is a condition of the connective tissue, which has movement ability beyond the normal limit of synovial joints. Its effects on disc degeneration and neck pain are not fully known. The aim of the present study was to determine the relationship between $\mathrm{GJH}$ and cervical disc degeneration that is detected in magnetic resonance imaging $(\mathrm{MRI})$ and also neck pain.
\end{abstract}

Methods: Cases aged between 20 and 50 years who were admitted to outpatient clinics with neck and arm pain were included in the study. Their cervical MRIs were evaluated. Beighton score was used to evaluate these cases for $\mathrm{GJH}$, and they were also evaluated prospectively using the Visual Analog Scale (VAS) for pain and Neck Disability Index (NDI) for disability.

Results: Of the 75 cases, 59 (78.7\%) were female, I6 (2I.3\%) were male, and GJH was found in 15 (20\%). There was no statistically significant difference in the values of Miyazaki grade parameters in all cervical disc levels and VAS and NDI values between the patients with and without $\mathrm{GJH}(\mathrm{p}>0.05)$.

Conclusion: This result suggests that GJH may not be a single risk factor for cervical disc degeneration, and VAS and NDI values increase in patients aged between 20 and 50 years.

\section{INTRODUCTION}

Generalized joint hypermobility $(\mathrm{GJH})$ is an observed phenomenon that may be inherited or very rarely acquired, which is defined as the ability to move the synovial joints beyond their normal range of motion (ROM). [1-3] Although its prevalence varies according to gender, age, and racial characteristics, it reaches to $15 \%$ in adults and $30 \%$ in childhood. ${ }^{[1,4]}$ The Beighton scoring system (Annex I) is used to detect $\mathrm{GJH} .{ }^{[5,6]}$ Cases with a score of $\geq 4$ according to this scoring system are classified as hypermobile, and these criteria can be determined by five simple maneuvers that take a maximum of I min for physicians to perform. ${ }^{[7,8]}$ Hypermobility (HM) plays an important role because of comorbid chronic pain complaints, premature osteoarthrosis, osteoporosis, and vascular and spinal disorders (scoliosis, spondylosis, and spondylolisthesis), and it may be overlooked especially when not searched for. ${ }^{[8,9]}$

The prevalence of chronic neck pain, which is a serious public health problem, has been reported to be between $30 \%$ and $50 \% .^{[10-12]}$ The effects of $\mathrm{HM}$ on cervical disc degeneration and neck pain, of which the prevalence is more than expected, are not known exactly. Nowadays, 
magnetic resonance imaging (MRI) is the most valid tool to evaluate disc pathology clinically. ${ }^{[13]}$ In this evaluation method, it is very important to use standard and reliable terminology in the evaluation of cervical disc degeneration, and the classification developed by Miyazaki et al. ${ }^{[14]}$ fulfills this requirement. To the best of our knowledge, there are not enough studies investigating the effect of HM on cervical intervertebral disc (IVD) degeneration. Therefore, the effect of GJH on the severity of disc degeneration and cervical pain was investigated based on cervical MRI findings by including cases aged between 20 and 50 years.

\section{MATERIALS AND METHODS}

The study was conducted with the approval of the ethics committee of İstanbul Fatih Sultan Mehmet Training and Research Hospital. The aim of the present study was to determine the effect of joint HM on cervical disc degeneration in patients aged between 20 and 50 years. Patients who had neck and/or arm pain were evaluated prospectively in the present study. The collected data were compared with a case-control study. Patients who had previously experienced trauma, neck surgeries, tumors, rheumatic diseases or infection, stroke, dementia, or intensive care treatment and those who were in the menopausal period were excluded from the study.

Table I. Beighton scoring system*

\begin{tabular}{l}
\hline Passive dorsiflexion of five metacarpal \\
joints beyond $90^{\circ}$ \\
Passive apposition of the thumb to the \\
flexor aspect of the forearm \\
Passive hyperextension of the elbow \\
beyond $10^{\circ}$ \\
Passive hyperextension of the knee \\
beyond $10^{\circ}$ \\
Hands rest flat on the floor when standing \\
upright with knees in extension \\
Total \\
"In adult patients, the cut-off value of Beighton score is 4 points from a total \\
of 9 points, and cases whose scores were $\geq 4$ points were considered as \\
patients with HM.
\end{tabular}

In the study period, 75 of the 278 patients who presented to the BS and FTR outpatient clinics with neck and/or arm pain were in compliance with our criteria. Demographic data, waist circumference values, and fingertip-to-floor (FTF) distance were recorded. Body mass index (BMI) was calculated, and cervical MRls obtained within the last 6 months were evaluated in patients who were eligible for the study and filled in the survey questionnaire forms in outpatient clinics. The Beighton scale scores (Table I) were used for the HM study in these cases. ${ }^{[5]}$ Cases with a score of $\geq 4$ according to the Beighton HM scoring system were classified as hypermobile. The severity of neck and/ or arm pain was evaluated by Visual Analog Scale (VAS), and clinical results were evaluated by the Turkish version of the Neck Disability Index (NDI). ${ }^{[15-18]}$

The evaluations of the MRls obtained within the last 6 months were performed by an expert radiologist (EDC MD) blinded to the study. In these cervical MRls of the cases, IVD degeneration at C2-3, C3-4, C4-5, C5-C6, C6-C7, and C7-Th I levels was classified using the Miyazaki grading system. ${ }^{[14]}$ In this grading system, disc degeneration is evaluated into five grades (Grades I-V) considering disc density and height (Table 2). Mean \pm standard deviations related to these five grades were calculated for each case, and the values were compared between the two groups.

\section{Statistical analysis}

Data were evaluated using IBM SPSS Statistics 22 (SPSS IBM, Turkey) programs for statistical analysis. ShapiroWilk test was used to study parameters with normal distribution. Descriptive statistical methods (mean, standard deviation, and frequency) were used for the evaluation of data. Student's t test was used for the intergroup comparison of quantitative data with normal distribution. MannWhitney $U$ test was used for the intergroup comparison of parameters without normal distribution. Fisher's exact test and Yates continuity correction test were used for the comparison of qualitative data. A $p$ value $<0.05$ was accepted as statistically significant.

\section{RESULTS}

Of the 75 cases who met the inclusion and exclusion criteria, 16 (21.3\%) were male, and 59 (78.7\%) were female. The mean age of the study group was $37.61 \pm 7.89$ years. Of the 75 cases, 15 had HM (Group A), and 60 had no HM

Table 2. Miyazaki classification of disc degeneration

\begin{tabular}{|c|c|c|c|c|}
\hline Grade & $\begin{array}{l}\text { Nucleus signal } \\
\text { intensity }\end{array}$ & Nucleus structure & $\begin{array}{l}\text { Distinction of nucleus } \\
\text { and annulus }\end{array}$ & Disc height \\
\hline 1 & Hyperintense & Homogenous white & Clear & Normal \\
\hline II & & Inhomogeneous with horizontal band, white & & \\
\hline III & Intermediate & Inhomogeneous gray to black & Unclear & Normal to decreased \\
\hline IV & & Inhomogeneous gray to black & Lost & \\
\hline V & Hypointense & Inhomogeneous gray to black & & Collapsed \\
\hline
\end{tabular}


Table 3. Evaluation of general characteristics according to the presence of generalized joint hypermobility

\begin{tabular}{|c|c|c|c|c|}
\hline & Group A & Group B & Total & $\mathbf{p}$ \\
\hline & Mean $\pm S D$ & Mean $\pm S D$ & Mean $\pm S D$ & \\
\hline Age (year) & $32.87 \pm 8.53$ & $37.37 \pm 7.95$ & $36.47 \pm 8.21$ & '0.057 \\
\hline \multicolumn{5}{|l|}{ Gender, n (\%) } \\
\hline Male & I (6.7) & $15(25)$ & $16(21.3)$ & ${ }^{3} 0.168$ \\
\hline Female & $14(93.3)$ & $45(75)$ & $59(78.7)$ & \\
\hline Waist circumference $(\mathrm{cm})$ & $83.07 \pm 11.83$ & $91.77 \pm 11.29$ & $90.03 \pm 11.85$ & ${ }^{\prime} 0.010^{*}$ \\
\hline Body mass index & $22.66 \pm 3.83$ & $26.59 \pm 4.52$ & $25.81 \pm 4.64$ & ${ }^{\prime} 0.003^{*}$ \\
\hline \multicolumn{5}{|c|}{ Fingertip-to-floor distance test, $\mathrm{n}(\%)$} \\
\hline Yes & $9(60)$ & II (I8.3) & $20(26.7)$ & ${ }^{3} 0.002^{*}$ \\
\hline No & $6(40)$ & $49(81.7)$ & $55(73.3)$ & \\
\hline \multicolumn{5}{|l|}{ Employment status, n (\%) } \\
\hline Employed & $8(53.3)$ & $33(55)$ & $4 \mathrm{I}(54.7)$ & ${ }^{2} \mathrm{I} .000$ \\
\hline Unemployed & $7(46.7)$ & $27(45)$ & $34(45.3)$ & \\
\hline \multicolumn{5}{|l|}{ Smoking status } \\
\hline Smoker & $4(26.7)$ & $19(31.7)$ & $23(30.7)$ & ${ }^{3} 1.000$ \\
\hline Non-smoker & II (73.3) & $4 I(68.3)$ & $52(69.3)$ & \\
\hline \multicolumn{5}{|l|}{ Additional disease, n (\%) } \\
\hline Yes & $6(40)$ & $19(31.7)$ & $25(33.3)$ & ${ }^{2} 0.759$ \\
\hline No & $9(60)$ & $41(68.3)$ & $50(66.7)$ & \\
\hline
\end{tabular}

'Student's t-test. ${ }^{2}$ Yates continuity correction. ${ }^{3}$ Fisher's exact test. ${ }^{*}<0.05$. SD: Standard deviation.

Table 4. Evaluation of study parameters according to the presence of generalized joint hypermobility

\begin{tabular}{|c|c|c|c|c|}
\hline & Group A & Group B & Total & $\mathbf{p}$ \\
\hline & Mean $\pm S D$ & Mean $\pm S D$ & Mean $\pm S D$ & \\
\hline Visual Analog Scale (median) & $5.87 \pm 1.36(6)$ & $6.4 \pm 1.77(6.5)$ & $6.29 \pm 1.7(6)$ & '0.343 \\
\hline Neck Disability Index & $49.53 \pm 18.55$ & $54.62 \pm 17.84$ & $53.6 \pm 17.98$ & ${ }^{2} 0.331$ \\
\hline
\end{tabular}

'Mann-Whitney U test. ${ }^{2}$ Student's t-test. ${ }^{3}$ Fisher's exact test. ${ }^{*}<0.05$. SD: Standard deviation.

Table 5. Evaluation of Miyazaki grading parameters according to the presence of generalized joint hypermobility

\begin{tabular}{|c|c|c|c|c|}
\hline \multirow[t]{2}{*}{ Miyazaki grade } & \multirow{2}{*}{$\frac{\text { Grup A }}{\text { Mean } \pm S D \text { (median) }}$} & \multirow{2}{*}{$\frac{\text { Grup B }}{\text { Mean } \pm S D \text { (median) }}$} & \multirow{2}{*}{$\frac{\text { Total }}{\text { Mean } \pm S D \text { (median) }}$} & \multirow[t]{2}{*}{$\mathbf{p}$} \\
\hline & & & & \\
\hline$C 2-3$ & $3.31 \pm 1.11$ (4) & $3.18 \pm 0.96(3)$ & $3.2 \pm 0.98$ & 0.373 \\
\hline C3-4 & $3.62 \pm 0.65(4)$ & $3.13 \pm 0.97(3)$ & $3.22 \pm 0.94(3)$ & 0.113 \\
\hline C4-5 & $3.69 \pm 0.75(4)$ & $3.23 \pm 1.1$ (3) & $3.32 \pm 1.05$ (3) & 0.207 \\
\hline C5-6 & $3.77 \pm 0.6(4)$ & $3.54 \pm 1.35$ (4) & $3.58 \pm 1.24(4)$ & 0.892 \\
\hline C6-7 & $3.23 \pm 0.83(3)$ & $2.91 \pm 1.21$ (3) & $2.97 \pm 1.15(3)$ & 0.444 \\
\hline C7-TI & $2.25 \pm 0.5(2)$ & $2 \pm 0.82(2)$ & $2.03 \pm 0.78(2)$ & 0.634 \\
\hline
\end{tabular}

Mann-Whitney $U$ test. SD: Standard deviation.

(Group B) (Table 3). In addition, I:4 equivalence design was used in comparison of cases with and without HM. There was no difference between these groups with respect to age, gender, smoking, previous diseases, and study status; however, a difference with respect to $\mathrm{BC}, \mathrm{BMI}$, and FTF data was remarkable (Table 3). The mean VAS scores were $5.87 \pm 1.36$ in Group A and $6.4 \pm 1.77$ in Group B.
However, no statistically significant difference was found between the two groups with respect to VAS density and NDI values (Table 4). In both groups, there was no difference in Miyazaki grades between cervical disc levels (Table 5). The degree of disc degeneration in Group A was higher than that in Group B in all examined disc levels, but this difference was not statistically significant. 


\section{DISCUSSION}

Despite the prevalence of HM in the community, its clinical effects are not fully understood, and there are not enough studies investigating the effect of cervical IVD degeneration and neck pain. The findings of our study on cases aged between 20 and 50 years revealed that HM did not cause neck pain and cervical disc degeneration in this age range (Tables 4 and 5). Since aging may complicate the evaluation of neck pain that may be directly or indirectly caused by HM, cases in the premenopausal period aged $<50$ years were included in our study.

However, to the best of our knowledge, there is only one study investigating the effect of HM on cervical disc degeneration and neck pain in patients who were not operated using the Miyazaki scoring system in the literature. Although the results of Lee et al. ${ }^{[19]}$ differed from our study, they included only cases in the 20-30 age group. With aging, the joint ROM decreases, which is true for hypermobile joints. ${ }^{[2]}$ In the literature, it is stated that disc degeneration is a progressing process with age. Although the majority of adults aged $>30$ years have a structural degeneration on one or more discs, degeneration in these cases is not always accompanied by pain. ${ }^{[13,21-24]}$

Furthermore, cervical disc herniation is usually seen in cases aged $>40$ years, different from lumbar disc herniation. ${ }^{[25,26]}$ Adams et al. ${ }^{[27]}$ showed that cadaveric discs aged $>50$ years are damaged even by minor traumas.

It has been suggested that impaired proprioception in HM has increased the tendency for sports injuries and thus joint injuries. ${ }^{[8,28]}$ In a meta-analysis by Pacey et al., ${ }^{\left[{ }^{[2]}\right]}$ it has been shown that knee injuries are more common than ankle injuries in hypermobile cases. In fact, knee joint is more susceptible to contact injury, and the joint ROM is greater than the ankle and remains between the relatively stable and mobile regions.

Decreased range of movement in one region and increased mobility of the other end due to HM may lead to faster and more severe degeneration of the in-between joint. As a matter of fact, it has been reported that the restriction of motion by posterior lumbar interbody fusion in HM cases leads to overload and movement in the neighboring segment, and as a result, it is reported that adjacent segment disease (ASD) occurs more easily and frequently in these cases. ${ }^{[28,30]}$ The study also confirmed this hypothesis, and it was shown that HM did not adversely affect fusion rate or clinical outcome (pain intensity or functional status) but had a negative effect on ASD. ${ }^{[3]}$ The same problem occurs after cervical stabilization. As a matter of fact, it has been reported that ASD can develop after anterior cervical discectomy and fusion (ACDF), and that male patients have higher risks for secondary surgery. ${ }^{[32-35]}$

In the meta-analyses, the incidence was reported to be lower for the second surgery in the cervical disc arthroplasty group than that in the ACDF group, and cervical artificial discs were preferred to reduce or delay the oc- currence of ASD. ${ }^{[36-39]}$ Currently, MRI is used as the most accurate non-invasive diagnostic tool that can detect the pathology of IVD at the earliest stage of degeneration. $[14,23,37,40]$ Degenerative changes in the disc are more frequently related to the reduction of water content. ${ }^{[14,41]}$ In the Miyazaki ${ }^{[14]}$ scoring system, for the evaluation of the degree of disc degeneration, the classification was based on both disk signal intensity and disc height categories.

Considering that the low signal intensity observed in disc degeneration in MRI has been shown to be mostly related to dehydration, disc dehydration in normal hypermobile cases will not increase under normal conditions; therefore, detection of increased degeneration in cervical MRI of these cases should not be expected. In addition, it has been shown that HM has a protective effect on osteoarthrosis in hand joints where the joint movement is intense. It is also suggested that increased joint motion in traumatic joints may not be the cause of degeneration alone ${ }^{[42]}$ Although HM is not referred to as a disease, the predominant complaint is usually widespread and longlasting pain, and it is also the most common cause of unexplained joint pains. ${ }^{[2,8]}$ However, in our study, we could not find any statistically significant difference not only between disc degeneration and HM but also between VAS and NDI values (Table 4).

The capsular ligaments of facet joints in the cervical spine are the main stabilizing structures. Steilen et al. ${ }^{[12]}$ reported that capsular ligament laxity is the main source of chronic neck pain, and that this pain reflects instability. In addition, Hogg-Johnson et al. ${ }^{\left[{ }^{[1]}\right]}$ reported that they could not find any evidence indicating that disc degeneration is a risk factor for neck pain. The results of all these studies show that neck pain is related to cervical pathologies caused by an overloading strain or trauma that may cause instability of capsular ligament rather than disc degeneration.

The fact that the cases we included in our study were selected among patients who were not exposed to trauma and lack of any difference between the workload of patients with and without HM (Table 3) may be the reason why any statistically significant difference was not found between the two groups with respect to neck pain.

One of the limitations of our study is that only disc degeneration was evaluated radiologically to reveal the relationship between HM and neck pain. Further studies should be performed on both the facet joints and capsular ligaments. Another limitation is that the study has been performed in a wide age range due to the small number of cases. Further studies on greater number of cases and separately in each decade may lead to more healthy outcomes.

\section{CONCLUSION}

In conclusion, there was no statistically significant relationship between $\mathrm{GJH}$ and cervical disc degeneration, VAS, and NDI. The tendency of patients with GJH to trauma will easily disrupt this harmony and will lead to faster and 
more aggravated development of joint degeneration. For this reason, it is necessary to avoid rigid stabilization especially in patients with $\mathrm{GJH}$ before spinal surgery.

In addition, these cases should be informed about starting paravertebral muscle strengthening exercises at an early age to avoid all types of traumas and to reduce the tendency to trauma.

Ethics Committee Approval

Approved by the İstanbul Fatih Sultan Mehmet Training and Research Hospital Ethics Committee (date: 23.11.2017, number: 2017/ 35).

Peer-review

Internally peer-reviewed.

Authorship Contributions

Concept: N.K., A.A. ?.?; Design: N.K., A.A., P.A.; Data collection \&/or processing: E.D.Ç., Ö.G.I., N.K., A.E.S.; Analysis and/or interpretation: E.D.Ç., N.K.; Literature search: A.A., A.E.S., N.K., Ö.G.i.; Writing: N.K., A.A.; Critical review: P.A., A.A., E.D.Ç.

Conflict of Interest

None declared.

\section{REFERENCES}

1. Baeza-Velasco C, Gély-Nargeot MC, Pailhez G, Vilarrasa AB. Joint hypermobility and sport: a review of advantages and disadvantages. Curr Sports Med Rep 2013;12:291-5. [CrossRef]

2. Simmonds JV, Keer RJ. Hypermobility and the hypermobility syndrome. Man Ther 2007;12:298-309. [CrossRef]

3. Suri P, Dharamsi AS, Gaviola G, Isaac Z. Are facet joint bone marrow lesions and other facet joint features associated with low back pain? A pilot study. PM R 2013;5:194-200. [CrossRef]

4. Adib N, Davies K, Grahame R, Woo P, Murray KJ. Joint hypermobility syndrome in childhood. A not so benign multisystem disorder? Rheumatology (Oxford) 2005;44:744-50. [CrossRef]

5. Beighton P, Solomon L, Soskolne CL. Articular mobility in an African population. Ann Rheum Dis 1973;32:413-8. [CrossRef]

6. Ross J, Grahame R. Joint hypermobility syndrome. BMJ 2011;342:c7167. [CrossRef]

7. Remvig L, Jensen DV, Ward RC. Are diagnostic criteria for general joint hypermobility and benign joint hypermobility syndrome based on reproducible and valid tests? A review of the literature. J Rheumatol 2007;34:798-803.

8. Simpson MR. Benign joint hypermobility syndrome: evaluation, diagnosis, and management. J Am Osteopath Assoc 2006;106:531-6.

9. Murray KJ. Hypermobility disorders in children and adolescents. Best Pract Res Clin Rheumatol 2006;20:329-51. [CrossRef]

10. Côté P, Cassidy JD, Carroll LJ, Kristman V. The annual incidence and course of neck pain in the general population: a population-based cohort study. Pain 2004;112:267-73. [CrossRef]

11. Hogg-Johnson S, van der Velde G, Carroll LJ, Holm LW, Cassidy JD, Guzman J, et al. The burden and determinants of neck pain in the general population: results of the Bone and Joint Decade 20002010 Task Force on Neck Pain and Its Associated Disorders. Spine 2008;33:S39-51. [CrossRef]

12. Steilen D, Hauser R, Woldin B, Sawyer S. Chronic neck pain: making the connection between capsular ligament laxity and cervical instability. Open Orthop J 2014;8:326-45. [CrossRef]
13. Cheung KM, Karppinen J, Chan D, Ho DW, Song YQ, Sham P, et al. Prevalence and pattern of lumbar magnetic resonance imaging changes in a population study of one thousand forty-three individuals. Spine (Phila Pa 1976) 2009;34:934-40. [CrossRef]

14. Miyazaki M, Hong SW, Yoon SH, Morishita Y, Wang JC. Reliability of a magnetic resonance imaging-based grading system for cervical intervertebral disc degeneration. J Spinal Disord Tech 2008;21:28892. [CrossRef]

15. Hawker GA, Mian S, Kendzerska T, French M. Measures of adult pain: Visual Analog Scale for Pain (VAS Pain), Numeric Rating Scale for Pain (NRS Pain), McGill Pain Questionnaire (MPQ), ShortForm McGill Pain Questionnaire (SF-MPQ), Chronic Pain Grade Scale (CPGS), Short Form-36 Bodily Pain Scale (SF-36 BPS), and Measure of Intermittent and Constant Osteoarthritis Pain (ICOAP). Arthritis Care Res (Hoboken) 2011;63 Suppl 11:S240-52.

16. Huskisson EC. Measurement of pain. Lancet 1974;2:1127-31.

17. Kesiktas N, Ozcan E, Vernon H. Clinimetric properties of the Turkish translation of a modified neck disability index. BMC Musculoskelet Disord 2012;13:25. [CrossRef]

18. Vernon H, Mior S. The Neck Disability Index: a study of reliability and validity.J Manipulative Physiol Ther 1991;14:409-15. [CrossRef]

19. Lee SM, Oh SC, Yeom JS, Shin JH, Park SG, Shin DS, et al. The impact of generalized joint laxity (GJL) on the posterior neck pain, cervical disc herniation, and cervical disc degeneration in the cervical spine. Spine J 2016;16:1453-8. [CrossRef]

20. Castori M, Hakim A. Contemporary approach to joint hypermobility and related disorders. Curr Opin Pediatr 2017;29:640-9. [CrossRef]

21. Boden SD, McCowin PR, Davis DO, Dina TS, Mark AS, Wiesel S. Abnormal magnetic-resonance scans of the cervical spine in asymptomatic subjects. A prospective investigation. J Bone Joint Surg Am 1990;72:1178-84. [CrossRef]

22. Kanayama M, Togawa D, Takahashi C, Terai T, Hashimoto T. Crosssectional magnetic resonance imaging study of lumbar disc degeneration in 200 healthy individuals. J Neurosurg Spine 2009;11:501-7.

23. Matsumoto M, Fujimura $Y$, Suzuki N, Nishi Y, Nakamura M, Yabe $Y$, et al. MRI of cervical intervertebral discs in asymptomatic subjects. J Bone Joint Surg Br 1998;80:19-24. [CrossRef]

24. Risbud MV, Shapiro IM. Role of cytokines in intervertebral disc degeneration: pain and disc content. Nat Rev Rheumatol 2014;10:4456. [CrossRef]

25. Ikeda H, Hanakita J, Takahashi T, Kuraishi K, Watanabe M. Nontraumatic cervical disc herniation in a 21 -year-old patient with no other underlying disease. Neurol Med Chir (Tokyo) 2012;52:652-6.

26. O'Laoire SA, Thomas DG. Spinal cord compression due to prolapse of cervical intervertebral disc (herniation of nucleus pulposus). Treatment in 26 cases by discectomy without interbody bone graft. J Neurosurg 1983;59:847-53. [CrossRef]

27. Adams MA, Freeman BJ, Morrison HP, Nelson IW, Dolan P. Mechanical initiation of intervertebral disc degeneration. Spine (Phila Pa 1976) 2000;25:1625-36. [CrossRef]

28. Kim HJ, Yeom JS, Lee DB, Kang KT, Chang BS, Lee CK. Association of benign joint hypermobility with spinal segmental motion and its clinical implication in active young males. Spine 2013;38:E1013-9.

29. Pacey V, Nicholson LL, Adams RD, Munn J, Munns CF. Generalized joint hypermobility and risk of lower limb joint injury during sport: a systematic review with meta-analysis. Am J Sports Med 2010;38:1487-97. [CrossRef]

30. Cakir B, Carazzo C, Schmidt R, Mattes T, Reichel H, Käfer W. Adjacent segment mobility after rigid and semirigid instrumentation of the lumbar spine. Spine (Phila Pa 1976) 2009;34:1287-91. [CrossRef]

31. Lee SM, Lee GW. The impact of generalized joint laxity on the clinical and radiological outcomes of single-level posterior lumbar inter- 
body fusion. Spine J 2015;15:809-16. [CrossRef]

32. Goffin J, Geusens E, Vantomme N, Quintens E, Waerzeggers Y, Depreitere B, et al. Long-term follow-up after interbody fusion of the cervical spine. J Spinal Disord Tech 2004;17:79-85. [CrossRef]

33. Hilibrand AS, Carlson GD, Palumbo MA, Jones PK, Bohlman $\mathrm{HH}$. Radiculopathy and myelopathy at segments adjacent to the site of a previous anterior cervical arthrodesis. J Bone Joint Surg Am 1999;81:519-28. [CrossRef]

34. Phillips FM, Geisler FH, Gilder KM, Reah C, Howell KM, McAfee PC. Long-term Outcomes of the US FDA IDE Prospective, Randomized ControlledClinical Trial Comparing PCM Cervical Disc Arthroplasty With AnteriorCervical Discectomy and Fusion. Spine (Phila Pa 1976) 2015;40:674-83. [CrossRef]

35. Wu JC, Liu L, Wen-Cheng H, Chen YC, Ko CC, Wu CL, et al. The incidence of adjacent segment disease requiring surgery after anterior cervical diskectomy and fusion: estimation using an 11-year comprehensive nationwide database in Taiwan. Neurosurgery 2012;70:594601. [CrossRef]

36. Hu Y, Lv G, Ren S, Johansen D. Mid- to Long-Term Outcomes of Cervical Disc Arthroplasty versus Anterior Cervical Discectomy and Fusion for Treatment of Symptomatic Cervical Disc Disease: A Systematic Review and Meta-Analysis of Eight Prospective Randomized
Controlled Trials. PLoS One 2016;11:e0149312. [CrossRef]

37. Shriver MF, Lubelski D, Sharma AM, Steinmetz MP, Benzel EC, Mroz TE. Adjacent segment degeneration and disease following cervical arthroplasty: a systematic review and meta-analysis. Spine J 2016;16:168-81. [CrossRef]

38. Yao Q, Liang F, Xia Y, Jia C. A meta-analysis comparing total disc arthroplasty with anterior cervical discectomy and fusion for the treatment of cervical degenerative diseases. Arch Orthop Trauma Surg 2016;136:297-304. [CrossRef]

39. Zhu Y, Tian Z, Zhu B, Zhang W, Li Y, Zhu Q. Bryan Cervical Disc Arthroplasty Versus Anterior Cervical Discectomy and Fusion for Treatment of Cervical Disc Diseases: A Meta-analysis of Prospective, Randomized Controlled Trials. Spine (Phila Pa 1976) 2016;41:E733-41. [CrossRef]

40. Modic MT, Masaryk TJ, Ross JS, Carter JR. Imaging of degenerative disk disease. Radiology 1988;168:177-86. [CrossRef]

41. Sambrook PN, MacGregor AJ, Spector TD. Genetic influences on cervical and lumbar disc degeneration: a magnetic resonance imaging study in twins. Arthritis Rheum 1999;42:366-72. [CrossRef]

42. Kraus VB, Li YJ, Martin ER, Jordan JM, Renner JB, Doherty M, et al. Articular hypermobility is a protective factor for hand osteoarthritis. Arthritis Rheum 2004;50:2178-83. [CrossRef]

\section{Generalize Eklem Hipermobilitesi ile Servikal Disk Dejenerasyonu ve Boyun Ağrısı Illişkisi: Bir Multidisipliner Klinik Çalışma}

Amaç: Generalize eklem hipermobilitesi (GEH) sinovial eklemlerin normal sınırın ötesinde hareket yeteneğinin olduğu bir durum olup disk dejenerasyonu üzerine etkileri bilinmemektedir. Çalışmamızın amacı GEH ile manyetik rezonans görüntülemede (MRG) saptanılan servikal disk dejenerasyonu ve boyun ağrısı arasındaki ilişkiyi ortaya çıkarmaktır.

Gereç ve Yöntem: Beyin cerrahisi ve fizik tedavi ve rehabilitasyon polikliniklerine boyun ve/veya kol ağrısı yakınması ile baş vuran 20-50 yaş arasındaki olgular çalışmaya alındı. Kriterlere uyan olguların servikal MRG'leri değerlendirildi. Bu olguları GEH yönünden değerlendirmede Beighton skoru kullanıldı. Olgular ayrıca Vizüel Analog Skala (VAS) kullanılarak ağrı, Boyun Dizabilite İndeksi (BDi) kullanılarak dizabilite yönünden ileriye dönük olarak değerlendirildiler.

Bulgular: Çalışma kriterlerine uyan 75 olgunun 59'u kadın (\%78.7), I6'sı erkek (\%2I.3), yaş ortalamaları 37.6I \pm 7.89 yıl idi. Olguların I5'inde GEH saptandı (\%20), 60'ında GEH'ye rastlanılmadı (\%80). GEH görülenlerle görülmeyenler arasında servikal disk düzeylerinde Miyazaki grade parametreleri açısından istatistiksel olarak anlamlı bir farklılık bulunmadı ( $p>0.05)$. Aynı şekilde gruplar arasında VAS ve BDi değerleri açısından da istatistiksel olarak anlamlı bir farklılık yoktu ( $p>0.05)$.

Sonuç: Bu sonuç 20-50 yaş aralığındaki olgularda, normal şartlar altında, GEH'nin servikal disk dejenerasyonu ile VAS ve BDI artışında tek başına bir risk faktörü olmayabileceğini düşündürmüştür.

Anahtar Sözcükler: Boyun ağrısı; boyun dizabilite indeksi; disk dejenerasyonu; generalize eklem hipermobilitesi; servikal omurga; Vizüel Analog Skala. 